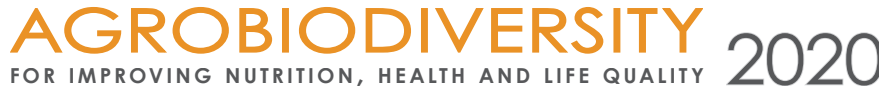

e

\section{CONTENT OF NUTRIENTS IN DIFFERENT PARTS OF IPOMOEA BATATAS L. (LAM.)}

\section{Vergun Olena*, Rakhmetov Dzhamal, Rakhmetova Svitlana, Fishchenko Valentyna, Shymanska Oksana}

M.M. Gryshko National Botanical Garden of the NAS of Ukraine, Kyiv, Ukraine

Received: 2. 11.2020 Revised: 12.11.2020 Published: 20.11.2020

Ipomoea batatas (L.) Lam. (sweet potato) is a popular food crop that is planted vegetatively and native to the American tropics. It is one of the most economically important crops alongside other that widely used in the world. This study was aimed to investigate the biochemical composition of plant raw material of I. batatas in conditions of M.M. Gryshko National Botanical Garden of the NAS of Ukraine. It was investigated the leaves, stems, and tubers at the end of vegetation. The content of dry matter, lipids, the total content of reducing sugars, tannins, titrable acidity, ascorbic acid, ß-carotene, total ash content, calcium, phosphorus, and the energetic value were detected. At the end of vegetation content of dry matter was from 13.00 to $25.45 \%$, the total content of sugars from 12.32 to $34.43 \%$, the titratable acidity from 1.82 to $5.48 \%$, the tannin content from 0.82 to $6.96 \%$, ascorbic acid content from 34.1 to $53.34 \mathrm{mg} \%$, the content of $ß$-carotene from 0.238 to $0.641 \mathrm{mg} \%$, lipids content from 1.89 to $6.93 \%$, total ash content from 2.1 to $11.99 \%$, calcium content from 0.53 to $1.86 \%$, phosphorus content from 0.51 to $1.81 \%$. The energetic value was in the range 3,242-3,623 Cal/g. Very strong positive correlation found between total tannin content and ash $(r=0.952)$, ß-carotene content and phosphorus $(r=0.919)$, total tannin content and titrable acidity $(r=0.845)$, ß-carotene content and lipids $(r=0.837)$. Plant parts of $I$. batatas contain functional and nutrient components that make it useful for the food industry. Obtained data can be used for the deep further biochemical, pharmacological study, and selective work.

Keywords: Ipomoea batatas, biochemical composition, correlation.

\section{Introduction}

Ipomoea batatas L. (Lam.) (sweet potato) belongs to the Convolvulaceae family is widely grown in tropical, subtropical, and warm temperate regions. It is widespread forage (Ruiz et al., 1980; Nguyen et al., 2004), food (Ababukar et al., 2010), medicinal, ritual, agricultural (Meira et al., 2012) crop in the world.

This plant has different pharmacological activities such as antioxidant, antiviral, antiinflammatory, hepatoprotective, gastroprotective, and immunomodulatory effects (Panda and

\footnotetext{
*Corresponding author: Olena Vergun, M.M. Gryshko National Botanical Garden of Ukraine of National Academy of Sciences, Kyiv, Olena Vergun, Timiryazevs ka 1, 01014 Kyiv, Ukraine en vergun@ukr.net
} 
Sonkamble, 2012). The antidiabetic potential I. batatas caused its bioactive compounds and isolated antidiabetic agents have a unique mechanism of action (Kusano et al., 2001; Akhtar et al., 2018). The most common biologically active compounds from Ipomoea spp. are ergoline alkaloids, indolizidine alkaloids, nortropane alkaloids, phenolic compounds, coumarins, norisoprenoids, diterpene, isocoumarin, glycolipids, lignan, triterpenes, etc. (Meira et al., 2012).

The study of the biochemical composition of leaves indicated the presence of amino acids (Ravindran et al., 1995), anthocyanin, polyphenols, vitamins, protein (Islam et al., 2002). The study of mineral composition of I. batatas tubers demonstrated the presence of iron (0.53-0.73 mg per $100 \mathrm{~g}$ ), zinc (0.23-0.27 mg per $100 \mathrm{~g}$ ), calcium (23.04-29.97 mg per $100 \mathrm{~g}$ ), magnesium (21.30-25.40 mg per $100 \mathrm{~g}$ ), phosphorus (42.0-46.33 mg per $100 \mathrm{~g}$ ), potassium (308.67-328.67 mg per $100 \mathrm{~g}$ ), and sodium (29.0-34.0 mg per $100 \mathrm{~g}$ ) (Sanoussi et al., 2016a).

According to Ababukar et al. (2010), the protein content in sweet potato leaf decoction was $12.41 \%$. This plant is a good source of dietary antioxidants (Alam et al., 2016). Leaf, stem, and root extracts of $I$. procumbens demonstrated the antioxidant and antimicrobial activity (Batiga et al., 2019). The essential oil from leaves of I. batatas contains monoterpenes, sesquiterpenes, diterpenes, abietadiene, $\beta$-caryophyllene, abieta-8, 11, 13-triene, trans(Z)- $\alpha$-bergamotol, cis-sabinen, etc. (Ogunmoye et al., 2015). Sweet potato can be used for bioethanol production (Swain et al., 2013). The influence of nitrogen fertilizer on biochemical parameters of $I$. batatas studied and it was indicated increasing of $\beta$-carotene and crude protein at 40-80 $\mathrm{kg} \mathrm{N} /$ ha (Ukom et al., 2009).

This study aimed to determine the peculiarities of biochemical compound accumulation in raw of two varieties of Ipomoea batatas (L.) Lam., which were grown in M. M. Gryshko National Botanical Garden of the NAS of Ukraine.

\section{Materials and methodology}

\section{Biological material}

This study investigated two varieties of Ipomoea batatas (L.) Lam. (f. 1 and f. 3). Plants collected from the experimental collection of the Department of Cultural Flora in M.M. Gryshko National Botanical Garden of the NAS of Ukraine (NBG) at the end of vegetation (at the beginning of October) during 2018-2019. Biochemical analyses were conducted in the laboratory of Department Cultural Flora of NBG. All investigated plants are annual.

\section{Biochemical analyses}

\section{Dry matter determination}

Plant samples were dried in a drying oven at $105^{\circ} \mathrm{C}$ till constant weight in aluminum boxes. Results are given in percentages (Yermakov et al., 1972). 


\section{The total content of sugars determination}

The total content of sugars was investigated by Bertrand's method in water extracts. $4 \mathrm{~g}$ of fresh mass mixed and homogenized with distilled water (approximately $50 \mathrm{ml}$ ) in the 100 $\mathrm{ml}$ test-tubes and heated in the water bath at $70{ }^{\circ} \mathrm{C}$ during $15-20 \mathrm{~min}$. After cooling in the obtained mixtures added $1 \mathrm{ml}$ of the phosphate-oxalate mixture. After this was added $1.5 \mathrm{ml}$ of lead acetate. The obtained mixture brings to the mark $(100 \mathrm{ml})$ with water. After filtration from the obtained solution took $50 \mathrm{ml}$ and mixed with $8 \mathrm{ml}$ of $20 \% \mathrm{HCl}$ (at the $70{ }^{\circ} \mathrm{C}$ in a water bath for $5 \mathrm{~min}$ ) and after cooling was neutralized by $12 \% \mathrm{NaOH}$ and brought to the mark by distilled water $(100 \mathrm{ml}) .3 \mathrm{ml}$ of obtained solution mixed with $6 \mathrm{ml}$ of Fehling's solution reagent ( 6 min boiling in the water bath). Obtained mixture analyzed for the total content of sugars. Results are given by percentages (Hrytsajenko et al., 2003).

\section{The total content of ascorbic acid}

Determination of ascorbic acid content conducted by method offered by K. Murri. $2 \mathrm{~g}$ of fresh mass mixed with $50 \mathrm{ml}$ of $2 \%$ oxalic acid. Obtained mixture put into the dark for $20 \mathrm{~min}$. Content of ascorbic acid of obtained extracts determined by a 2.6-dichlorophenol-indophenol method that is based on the reduction properties of ascorbic acid. Obtained results were expressed in the mg\% DW (Hrytsajenko et al., 2003).

\section{The total content of $ß$-carotene}

The concentration of total carotene determined according to Pleshkov (1985) using extraction with rubber solvent (petrol). $1 \mathrm{~g}$ of absolutely dried raw mixed with $20 \mathrm{ml}$ of Kalosha petrol for 2 hours. After this obtained filtrate measured spectrophotometrically at the wavelength 440 $\mathrm{nm}$ at the Unico spectrophotometer. Obtained results expressed in $\mathrm{mg} \% \mathrm{DW}$. This parameter is determined in the leaves and stems.

\section{The total content of tannins}

The content of tannins was determined with indigo carmine as an indicator (Yermakov et al., 1972). $5 \mathrm{~g}$ of fresh mass mixed with distilled water (approximately $50 \mathrm{ml}$ ) in $100 \mathrm{ml}$ tastetubes. Obtained mixture heated in the water bath at $70{ }^{\circ} \mathrm{C}$ for 2 hours. After cooling, adding water to the $100 \mathrm{ml}$, and following filtration $10 \mathrm{ml}$ of filtrate used for the determination of the total content of tannins. This procedure used $700 \mathrm{ml}$ distilled water and $25 \mathrm{ml}$ of $1 \%$ solvent of indigo carmine. Obtained results expressed in \%.

\section{The total content of organic acids}

The total content of organic acids is determined with phenolphthalein and results calculated with a malic acid coefficient (Krishchenko, 1983). $10 \mathrm{ml}$ of filtrate (the same procedure described for the determination of total content of tannins) titrated with $1 \mathrm{~N}$ solvent of $\mathrm{NaOH}$ in presence of phenolphthalein. Obtained results expressed in percentages.

\section{The total ß-content of lipids}

The total content of lipids is determined using the Soxhlet extractor. Dried raw was extracted with petroleum ether (boiling temperature $40-60^{\circ} \mathrm{C}$ ) according to Yermakov et al. (1972). 


\section{The total content of ash, calcium, and phosphorus}

The total content of ash is determined by combustion in the muffle-oven at $200-500{ }^{\circ} \mathrm{C}$ for 3 days considering the mass before and after combustion (Hrytsajenko et al., 2003). After the combustion procedure ash was used to determining calcium and phosphorus content. Total calcium content was detected by Trilon-B titration (Hrytsajenko et al., 2003). Phosphorus content determined dissolving ash in the nitric acid (1:5), after the routing procedure with adding molybdenum reactive, mixtures were titrated with sodium hydroxide (Pochinok, 1976).

\section{Energetic value}

The procedure of caloricity measurement conducted using calorimeter IKA C-200 (Germany). 0.1-0.2 g of dried plant raw material was combusted in an oxygen bomb for approximately 15 minutes.

\section{Statistical analysis}

The mean values of three replicates and the standard deviation are given. Data submitted with ANOVA and differences between means compared using the Tukey-Kramer test $(\alpha=0.05)$. Correlation analysis performed using Pearson's criterion.

\section{Results and discussion}

The biochemical composition study of crops is a very important part of investigations to evaluate nutrition value. Among other parameters, should be highlighted dry matter content (Shipley and $\mathrm{Vu}, 2002$ ) and the total content of sugars that also play a significant role in plant tolerance to stress factors (Sami et al., 2016). The content of dry matter was from 13.00 to $25.45 \%$ depending on the plant part (Figure 1).

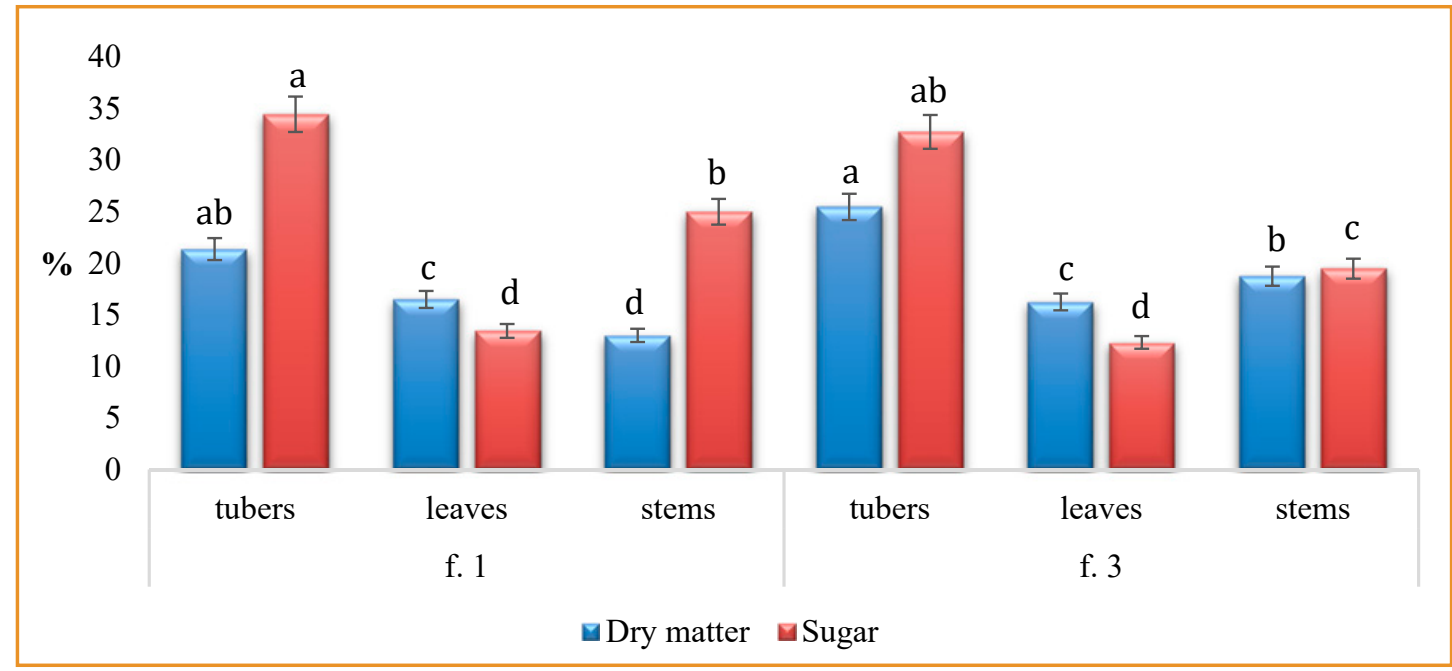

Figure 1 The total content of sugars and dry matter of the plant raw material of Ipomoea batatas (L.) Lam. at the end of vegetation (means in columns followed by different letters are different at $p<0.05$. Each value represents the mean of three independent experiments $( \pm \mathrm{SD})$ ) 
The most value of dry matter found in the tubers of I. batatas. Also, tubers accumulated the most sugars comparing with other plant parts, while leaves had the least content of it. At all, the total content of sugars was $12.32-34.43 \%$.

A study of the chemical composition of sweet potato dishes showed that the content of moisture in leaf soup varied from 35.15 to $70.54 \%$ and carbohydrate content was $25.74-70.00 \%$ (Ababukar et al., 2010). According to Dinu et al. (2018), the dry matter content of sweet potato blades and petioles were 16.0-18.5 and 12.3-16.0\%, respectively. Also, it was reported that reducing sugars content was 23.80-51.91\%, depending on the cultivar and plant part. As reported Hossain et al. (2019), the dry matter content of three I. batatas varieties detected from 30.3 to $34.5 \%$, sugars from 10.61 to $11.82 \%$. Nascimento et al. (2015) reported that total carbohydrates content in tubers was 41.08-73.43\%. According to Ravindran et al. (1995), dry matter content of $I$. batatas cultivars was in a range of $30.6-37.2 \%$.

The ascorbic acid content one of the important parameters to evaluate the nutritive quality of plant raw material. Ascorbic acid as a biochemical compound acts as an enzyme cofactor, as a radical scavenger, and as a donor/acceptor on electron transport either at the plasma membrane or in the chloroplasts (Davey et al., 2000). The raw of f. 1 ascorbic acid accumulated in the range $34.1-53.34 \mathrm{mg} \%$ and $\mathrm{f} .3$ in a range of $18.86-64.03 \mathrm{mg} \%$ (Figure 2). Carotenoids are natural pigments, including $ß$-carotene, lycopene, lutein, etc. Among the carotenoids, the $ß$-carotene one of the most widespread groups of secondary metabolites with high bioactivity (Bogacz-Radomska and Harasym, 2018). The content of ß-carotene in our study was 0.238$0.641 \mathrm{mg} \%$ for both varieties.

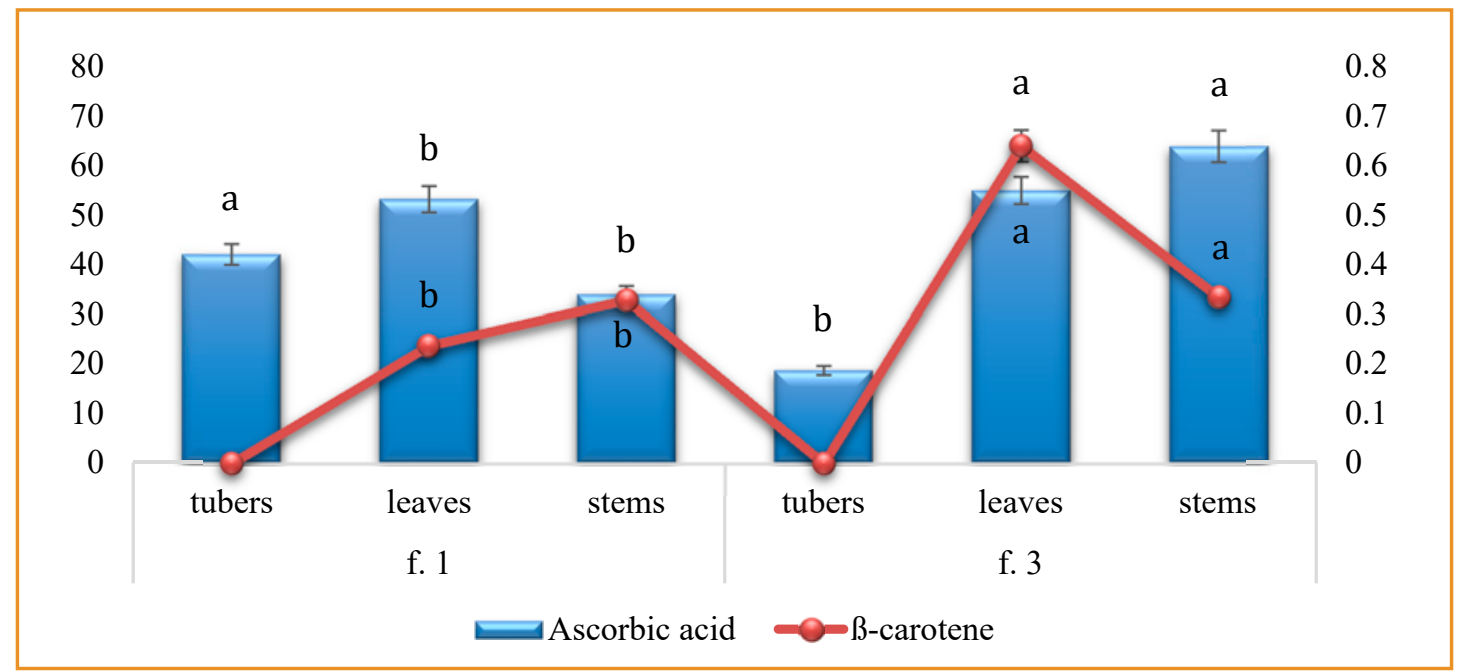

Figure 2 The content of ascorbic acid and ß-carotene in the plant raw material of Ipomoea batatas (L.) Lam. at the end of vegetation, $\mathrm{mg} \%$ (means in columns followed by different letters are different at $p<0.05$. Each value represents the mean of three independent experiments $( \pm \mathrm{SD})$ )

Alam et al. (2016) reported the total content of carotenoids in different $I$. batatas varieties from Bangladesh was from 0.38 to $7.24 \mathrm{mg} \%$. According to Dinu et al. (2018), carotene content in the blade and petiole extracts was 23.80-25.05 and 16.39-16.60 mg\%, respectively. Sweet 
potato leaves accumulated ascorbic acid content of 3.56-5.96 mg\% that is approximately 10 times less than our study. As reported Nascimento et al. (2015), the total carotenoid content in tubers was $3182.0 \mu \mathrm{g}$ per $100 \mathrm{~g}$. Sri Lankan cultivars had an average sugars content of $6 \mathrm{~g}$ per 100 g DW (Ravindran et al., 1995).

The most content of tannins in the raw of investigated I. batatas identified in the leaves and the least in the tubers \% (Figure 3). At all, tannins accumulated in a quantity of $0.82-6.96 \%$. Titrable acidity is determined from 1.82 to $5.48 \%$, depending on the plant part and variety. Li et al. (2017) found that tannin content for different cultivars of sweet potato was 2.28-4.46 mg per $100 \mathrm{~g}$.

The total lipid content in different parts of $I$. batatas plants was in the range of $1.89-6.93 \%$ (Figure 3).

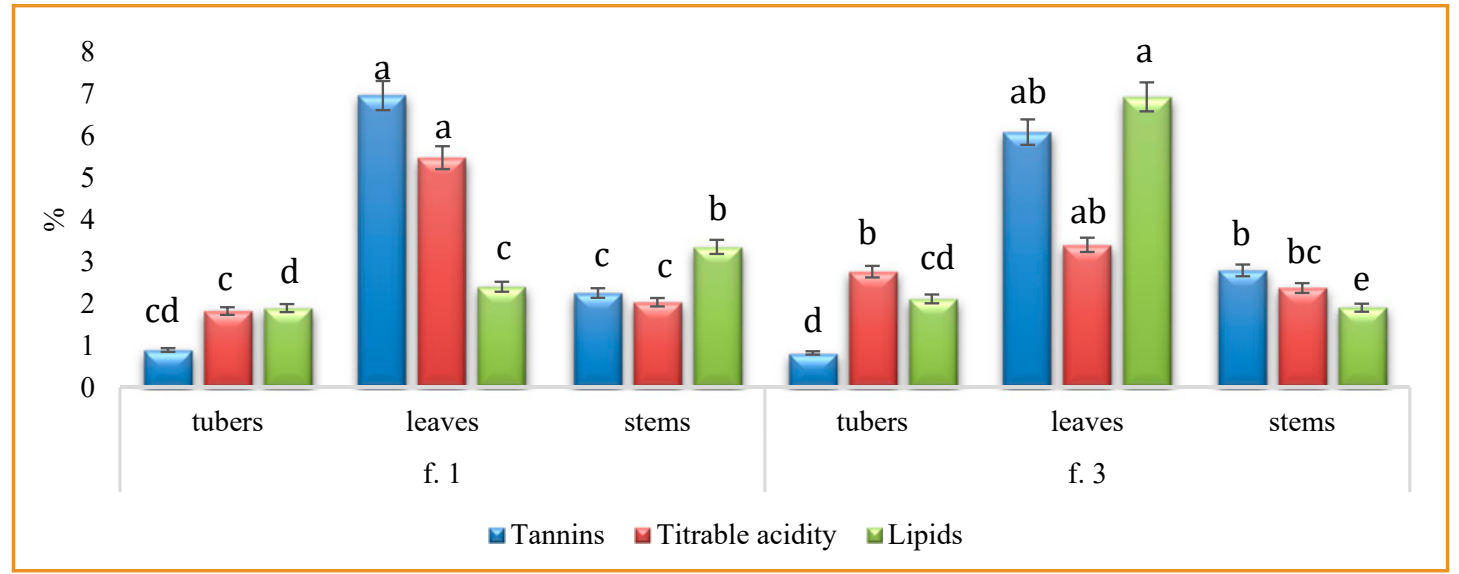

Figure 3 The content of tannins, titrable acidity, and lipids in the plant raw material of Ipomoea batatas (L.) Lam. at the end of vegetation (means in columns followed by different letters are different at $p<0.05$. Each value represents the mean of three independent experiments $( \pm \operatorname{SD})$ )

The highest content of it is identified in the leaves of f. 3 plants. Lipids are important biochemical compounds that play numerous biological functions and accumulated in the seeds (Vergun et al., 2017), leaves, stems, rhizomes (Andrushchenko et al., 2018), tubers (Ramadan and Oraby, 2016), etc.

The fat content in tubers of 16 cultivars of Sri Lankan sweet potato was in a range of 1.07-2.14 g per $100 \mathrm{~g}$ DW (Ravindran et al., 1995). The fat content of I. batatas dishes ranged from 0.30 to $3.88 \%$ and tannin content from $0.22-0.86 \mathrm{mg}$ per $100 \mathrm{~g}$ (Ababukar et al., 2010). According to Nascimento et al. (2015), fat content in the sweet batatas tubers was $0.19-4.50 \%$ and proteins $0.58-2.53 \%$.

The most content of ash among investigated varieties of $I$. batatas found in the leaves and the least in the tubers (Figure 4). At all, the total content of ash was from 2.1 to $11.99 \%$. The concentration of calcium was from 0.53 to $1.86 \%$ and phosphorus from 0.51 to $1.81 \%$. As reported Ravindran et al. (1995), the calcium content in tubers of these plants was 89-239 mg 
per $100 \mathrm{~g}$ DW and phosphorus 148-226 mg per $100 \mathrm{~g}$ DW. According to Ababukar et al., 2010, the ash content of sweet potato dishes varied from 1.13 to $8.83 \%$, and the concentration of calcium was determined from 19.19 to $27.99 \mathrm{mg}$ per $100 \mathrm{~g}$. Ash content in tubers, as reported Nascimento et al. (2015), was 0.85-1.29\% depending on cultivar.

The energetic value was identified in the leaves and stems and was from 3242 to $3623 \mathrm{Cal} / \mathrm{g}$.

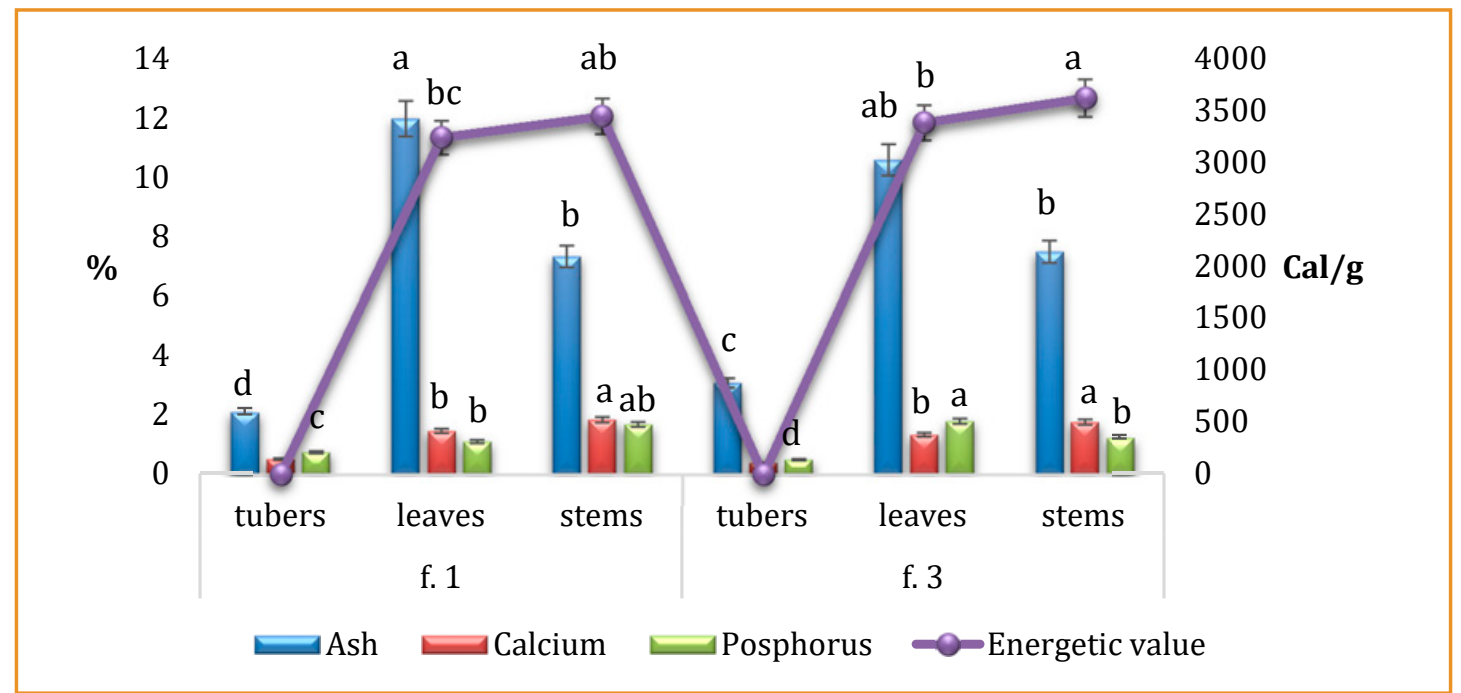

Figure 4 The content of ash, calcium, phosphorus, and energetic value in the plant raw material of Ipomoea batatas (L.) Lam. at the end of vegetation (means in columns followed by different letters are different at $p<0.05$. Each value represents the mean of three independent experiments $( \pm \mathrm{SD})$ )

Very strong positive correlation found between carotene content with lipids ( $r=0.837)$, and with phosphorus $(r=0.919)$. Total tannin content correlated with titrable acidity $(r=0.845)$ and with ash content $(r=0.952)$. Strong correlation found between dry matter and sugars content $(r=0.637)$, titrable acidity and ash $(r=0.750)$, lipids and phosphorus $(r=0.740)$. Ascorbic acid content correlated strongly with carotene content $(r=0.600)$, total tannin content $(r=0.614)$, and ash content $(r=0.620)$, etc. Also, strong relations determined between ash content and its components.

According to Sanoussi et al. (2016b), dry matter content of I. batatas positively correlated with carbohydrate content and energy value. Total sugar content is also positively correlated with energy value. Li et al. (2017) found negative correlation between tannin content and ß-carotene $(r=-0.214)$ content while in our study correlation was determined as strong $(r=0.676)$. Analise of data concerning biochemical composition of $I$. batatas petiole and leaf showed a very strong positive correlation between total phenolic compounds and reducing sugars, and their extracts exhibited the antioxidant activity that correlated with phenolic compounds (Dinu et al., 2018). Biochemical composition of I. batatas depending on geographical location, climate, weather, heat treatment, and terrestrial factors as seen from the previous report (Shariff et al., 2017). 


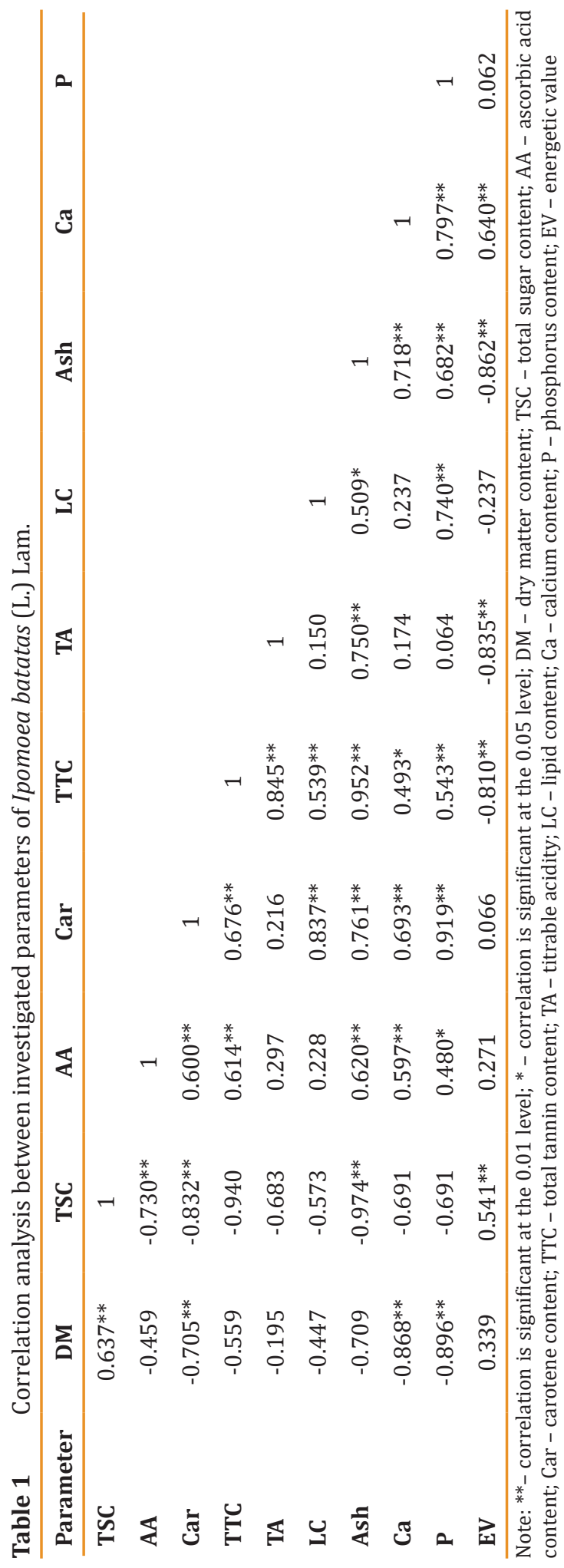




\section{Conclusions}

Thus, in M.M. Gryshko National Botanical Garden two varieties of I. batatas investigated for selected biochemical parameters and it was indicated that plant raw material accumulated a high content of nutrients. The highest content of dry matter and sugars found in tubers, ascorbic acid, ß-carotene, tannin content, lipids, ash in leaves and stems depending on the variety. Between some investigated parameters detected a very strong positive correlation such as carotene content and lipids, carotene and phosphorus, total tannin content with titrable acidity, and ash content. Strong correlation found between dry matter and sugars content, titrable acidity, and ash, lipids, and phosphorus. Obtained data can be used for the deep further biochemical, pharmacological study, and selective work.

\section{Acknowledgements}

The publication was prepared with the active participation of researchers in the international network AgroBioNet.

\section{References}

ABUBAKAR, H.N., OLAYIWOLA, I.O., SANNI, S.A., IDOWU, M.A. 2010. Chemical composition of sweet potato (Ipomoea batatas L.) dishes as consumed in Kwara state, Nigeria. In International Food Research Journal, vol. 17, p. 411-416.

AKHTAR, N., AKRAM, M., DANIYAL, M., AHMAD, S. 2010. Evaluation of antidiabetic activity of Ipomoea batatas L. extract in alloxan-induced diabetic rats. In International Journal of Immunopathology and Pharmacology, vol. 32, p. 1-6. https://doi.org/10.1177/2058738418814678

ALAM, M.K., RANA, Z.H., ISLAM, S.N. 2016. Comparison of the proximate composition, total carotenoids and total polyphenol content of nine orange-fleshed sweet potato varieties grown in Bangladesh. In Foods, vol. 5, 64. https://doi.org/10.3390/foods5030064

ANDRUSHCHENKO, O., VERGUN, O., FISHCHENKO, V., MISHCHENKO, L. 2018. Biochemical composition Polimnia sonchifolia Poepp. at double cutting. In Agrobiodiversity for Improving Nutrition, Health and Life Quality, vol. 2, p. 243-249. https://doi.org/10.15414/ agrobiodiversity.2018.2585-8246.243-249

BATIGA, S., VALLI, M., ZERAIK, M.L., FRAIGE, K., LEME, G.M., PITANGUI, N.S., ALMEIDA, A.M.F., MICHEL, S., YOUNG, M.C.M., BOLZANI, V.S. 2019. Chemical composition and biological properties of Ipomoea procumbens. In Brazilian Journal of Pharmacognosy, vol. 29, p. 191-197. https://doi.org/10.1016/j. bjp.2018.08.010

BOGACZ-RADOMSKA, L., HARASYM, J. 2018. ß-carotene properties and production method. In Food Quality and Safety, vol. 2, p. 69-74. https://doi.org/10.1093/fqsafe/fyy004DAVEY, M.W., MONTAGU, M.V., INZE, D., SANMARTINE, M., KANELLIS, A., SMIRNOFF, N., BENZIE, I.J.J., STRAINE, J.J., FAVELL, D., FLETCHER, J. 2000. Plant L-ascorbic acid: chemistry, function, metabolism, bioavailability and effects of processing. In Journal of the Science of Food and Agriculture, vol. 80, p. 825-860.

DINU, M., SOARE, R., BĂBEANU, C., HOZA, G. 2018. Analysis of nutritional composition and antioxidant activity of sweet potato (Ipomoea batatas L.) leaf and petiole. In Journal of Applied Botany and Food Quality, vol. 91, p. 120-125. https://doi.org/10.5073/JABFQ.2018.091.017

HOSSAIN, B. 2019. Study on the physicochemical composition and antioxidant properties of selected colored sweet potato variety (Ipomoea batatas L.) in Bangladesh. In Journal of Experimental Food Chemistry, vol. 5(1), 138.

HRYTSAJENKO, Z.M., HRYTSAJENKO, V.P., KARPENKO, V.P. 2003. Metody biologichnyh ta agrohimichnyh doslidgen roslyn i gruntiv (Methods of biological and agrochemical investigations of plants 
and soils). Kyiv : Nichlava, 320 p. ISSN: 966-7317-84-6. Available at: http://lib.udau.edu.ua/ handle/123456789/1547 [In Ukrainian].

ISLAM, M.S., YOSHIMOTO,M., TERAHARA, N., YAMAKAWA, O. 2002. Anthocyanin compositions in sweetpotato (Ipomoea batatas L.) leaves. In Bioscience, Biotechnology, and Biochemistry, vol. 66(11), p. 2483-2486.

KRISHCHENKO, V.P. 1983. Metody otsenki kachestva rastitelnoy produktsii (Methods of evaluation of plant production quality). M : Kolos, 192 p. [In Russian].

KUSANO, SH., ABE, H., TAMURA, H. 2001. Isolation of antidiabetic components from white-skinned sweet potato (Ipomoea batatas L.). In Bioscience, Biotechnology, and Biochemistry, vol. 65(1), p. 109-114.

LI, M., JANG, G.Y., LEE, S.H., KIM, H.S., LEE, J., JEONG, H.S. 2017. Comparison of functional components in various sweet potato leaves and stalks. In Food Science and Biotechnology, vol. 26, p. 97-103. https://doi.org/10.1007/s10068-017-0013-6

MEIRA, M., SILVA, E.P., DAVID, J.M., DAVID, J.P. 2012. Review of the genus Ipomoea: traditional uses, chemisry and biological activities. In Brazilian Journal of Pharmacognosy, vol. 22(3), p. 682-713. https://dx.doi.org/10.1590/S0102-695X2012005000025

NASCIMENTO, K.O., LOPES, D.S., TAKEITI, C.Y., BARBOSA, J.L., BARBOSA, M.I.M.J. 2015. Physicochemical characteristics of tubers from organic sweet potato roots. In Revista Caatinga, vol. 28(2), p. 225-234.

NGUYEN, L., EVERTS, H., HUE, H., BEYNEN, A.C. 2004. Feeding of spinach or sweet potato leaves and growing pigs kept on smallholder farms in Central Vietnam. In Tropical Animal Health and Production, vol. 36, p. 815-822. https://doi.org/10.1023/B:TROP.0000045958.84521.ab

OGUNMOYE, A.R.O., ADEBAYO, M.A., INIKPI, E., OGUNWANDE, I.A. 2015. Chemical constituents of essential oil from the leaves of Ipomoea batatas L. (Lam.). In International Research Journal of Pure \& Applied Chemistry, vol. 7(1), p. 42-48.

PANDA, V., SONKAMBLE, M. 2012. Phytochemical constituents and pharmacological activities of Ipomoea batatas L. (Lam.) - a review. In International Journal of Research in Phytochemistry \& Pharmacology, vol. 2(1), p. 25-34.

PLESHKOV, B.P. 1985. Praktikum po biohimii rastenii [Plant biochemistry workshop]. Moscow : Kolos, 256 p. [In Russian]

POCHINOK, H.N. 1976. Metody biohimicheskogo analiza rastenii [Methods of biochemical analysis of plants]. Kyiv : Naukova dumka. 334 p. [In Rassian]

RAMADAN, M.F., ORABY, H.F. 2016. Fatty acids and bioactive lipids of potato cultivars: an overview. In Journal of Oleo Science, vol. 65(6), p. 459-470. https://doi.org/10.5650/jos.ess16015

RAVINDRAN, V., RAVINDRAN, G., SAVAKANESAN, R., RAJAGURU, S.B. 1995. Biochemical and nutritional assessment of tubers from 16 cultivars of sweet potato (Ipomoea batatas L.). In Journal of Agricultural Food Chemistry, vol. 43, p. 2646-2651.

RUIZ, M.E., PEZO, D., MARTINEZ, L. 1980. The use of sweet potato (Ipomoea batatas (L.) Lam.) in animal feeding: agronomic aspects. In Tropical Animal Production, vol. vol. 5(2), p. 144-151.

SAMI, F., YUSUF, M., FAIZAN, M., FARAZ, A., HAYAT, SH. 2016. Role of sugars under abiotic stress. In Plant Physiology and Biochemistry, vol. 109, p. 54-61. http://dx.doi.org/10.1016/j.plaphy.2016.09.005

SANOUSSI, A.F., ADJATIN, A.A., DANSI, A., ADEBOWALE, A., SANNI, L.O., SANNI, A. 2016a. Mineral composition of ten elites sweet potato (Ipomoea batatas (L.) Lam.) landraces of Benin. In International Journal of Current Microbiology and Applied Sciences, vol. 5(1), p. 103-115. https:// dx.doi.org/10.20546/ijcmas.2016.501.009

SANOUSSI, A.F., DANSI, A., AHISSOU, H., ADEBOWALE, A., SANNI, L.O., OROBIYI, A., DANSI, M., AZOKROTA, P., SANNI, A. 2016b. Possibilities of sweet potato (Ipomoea batatas (L.) Lam.) value chain upgrading 
as revealed by physico-chemical composition of ten elites landraces of Benin. In African Journal of Biotechnology, vol. 15(13), p. 481-489. https://doi.org/10.5897/AJB2015.15107

SHARIFF, A.H.M., MEI, W.M., YAHYA, A., SALLEH, M.M., IQBAL, N., KADIR, W.R.W.A., AHMAD, R., SHARAANI, S.M., NORDIN, M.F.M., ZAKARIA, M. 2017. Biochemical content of two sweet potatoes (Ipomoea batatas) cultivars under dry heat and moist heat treatment. In Transaction on Science and Technology, vol. 4(3), p. 224-231.

SHIPLEY, B., VU, T.-T. 2002. Dry matter content as a measure of dry matter concentration in plants and their parts. In New Physiologist, vol. 153, p. 359-364.

SWAIN, M.R., MISHRA, J., THATOI, H. 2013. Bioethanol production from sweet potato (Ipomoea batatas L.) flour using co-culture of Trichoderma sp. And Saccharomyces cerevisiae in solid-state fermentation. In Brazilian Archives of Biology and Technology, 56(2), p. 171-179.

VERGUN, O., RAKHMETOV, D., FISHCHENKO, V., RAKHMETOVA, S., SHYMANSKA, O., DRUZ, N., BOGATEL, L. 2017. The lipid content in the seeds of Brassicaceae Burnett family. In Agrobiodiversity for Improving Nutrition, Health and Life Quality, vol. 1, p. 493-497. https://dx.doi.org/10.15414/ agrobiodiversity.2017.2585-8246.493-497

UKOM, A.N., OJIMELUKWE, P.C., OKPARA, D.A. 2009. Nutrient composition of selected sweet potato (Ipomoea batatas (L.) Lam.) varieties as influenced by different levels of nitrogen fertilizers application. In Pakistan Journal of Nutrition, vol. 8(11), p. 1791-1795.

YERMAKOV, A.I., ARASIMOVICH, V.V., SMIRNOVA-IKONNIKOVA, M.I., YAROSH, N.P. 1972. Metody biohimicheskoho issledovaniia rastenii (The methods of biochemical investigations of plants). Leningrad: Kolos, 456 p. [In Russian] 